
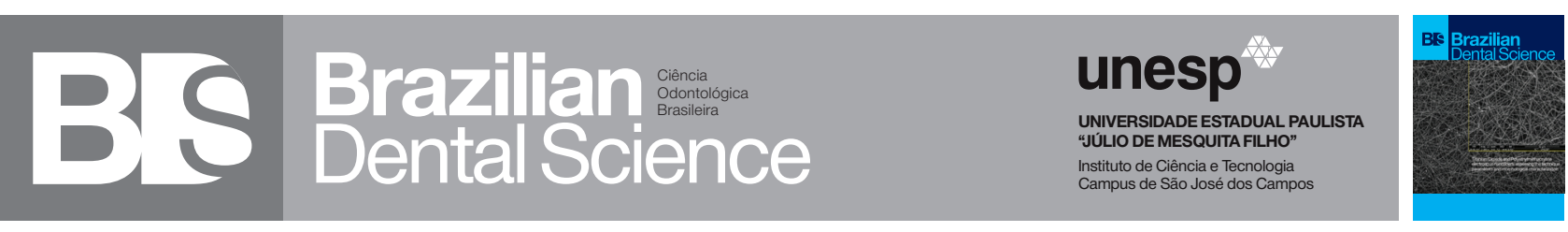

\title{
Use of Cone Beam Computed Tomography to Identify the Morphology of Maxillary and Mandibular Premolars in Chennai Population
}

Uso de Tomografia Computadorizada de Feixe Cônico para Identificar a Morfologia de Pré-Molares Maxilares e Mandibulares na População Chennai

Rajamohan RAJAKEERTHI ${ }^{1}$, Malli Suresh Babu NIVEDHITHA ${ }^{2}$

1 - Post Graduate, Department of Conservative Dentistry and Endodontics - Saveetha Dental College - Saveetha Institute of Medical and Technical Sciences - Chennai - India.

2 - Professor and Head, Department of Conservative Dentistry and Endodontics - Saveetha Dental College - Saveetha Institute of Medical and Technical Sciences - Chennai - India.

\section{ABSTRACT}

Objective: The complex root canal anatomy is inherently colonised by microbial flora. Endodontic treatment success is always related to adequate disinfection of the root canal space, which ultimately affects the treatment outcome. A thorough understanding of the external and internal root canal anatomy by using adequately imaging modalities is essential before planning any treatment. The aim of this study was to investigate the number and morphology of the root canals of maxillary and mandibular premolars in Chennai population. Material and Methods: Full-size cone-beam computed tomographic images were randomly collected from 100 patients, resulting in a total of 200 first and 200 second maxillary premolars as well as 200 first and 200 second mandibular premolars. All the eight premolars were analysed in single patients, who underwent cone-beam computed tomography scanning during pre-operative assessment (before implant surgery, orthodontic treatment, diagnosis of dental-alveolar trauma or difficult root canal treatment). Total number of roots and root canals, frequency and correlations between men and women were recorded and statistically analysed by using chi-square tests. The root canal configurations were rated according to the Vertucci's classification. Results: In the maxillary first premolar group ( $\mathrm{n}=200), 36.3 \%$ had 1 root, $56.7 \%$ had 2 roots and $7.0 \%$ had 3 roots, with most exhibiting a type IV canal configuration. In the maxillary second premolar group $(n=200)$, $60 \%$ had 1 root, $29.8 \%$ had 2 roots and $10.2 \%$ had 3 roots, with the majority of single-rooted second premolars exhibiting a type I canal configuration. In the mandibular first premolar group $(n=200)$,

\section{RESUMO}

Objetivo: A complexa anatomia do canal radicular é inerentemente colonizada pela flora microbiana. O sucesso do tratamento endodôntico está sempre relacionado à desinfecção adequada do espaço do canal radicular, o que definitivamente afeta o desfecho terapêutico. Uma compreensão clara da anatomia interna e externa do canal radicular através do uso adequado de modalidades de imagem é essencial antes do planejamento de qualquer tratamento. O objetivo deste estudo foi investigar o número e a morfologia dos canais radiculares de pré-molares maxilares e mandibulares na população Chennai. Material e Métodos: Imagens tomográficas de feixe cônico em tamanho real foram aleatoriamente coletadas de 100 pacientes, resultando em um total de 200 primeiros e 200 segundos pré-molares maxilares assim como em 200 primeiros e 200 segundos pré-molares mandibulares. Foram analisados todos os oito pré-molares de um único paciente após avaliação pré-operatória (antes de cirurgia de implante dentário, tratamento ortodôntico e diagnóstico de trauma dentoalveolar ou tratamento endodôntico difícil). O número total de raízes e canais radiculares, a freqüência e as correlações entre homens e mulheres foram registrados e estatisticamente analisados usando-se testes chi-quadrado. As configurações dos canais radiculares foram classificadas conforme a classificação de Vertucci. Resultados: No grupo de primeiros pré-molares maxilares $(n=200)$, $36.3 \%$ tinham 1 raiz, $56.7 \%$ tinham 2 raízes e $7.0 \%$ tinham 3 raízes, com a maioria exibindo configuração tipo IV. No grupo de segundos pré-molares maxilares $(n=200), 60 \%$ tinham 1 raiz, 29.8\% tinham 2 raízes e $10.2 \%$ tinham 3 raízes, com a maioria dos dentes de raiz única exibindo configuração tipo I. No grupo de primeiros pré-molares mandibulares ( $\mathrm{n}=200)$, $80.5 \%$ tinham 1 raiz, $9.8 \%$ tinham 2 raízes e $5 \%$ 
$80.5 \%$ had 1 root, $9.8 \%$ had 2 roots and $5 \%$ had 3 roots. In the mandibular second premolar group $(\mathrm{n}=200), 90.1 \%$ had 1 root, $6.4 \%$ had 2 roots and $3.5 \%$ had 3 roots, with most exhibiting a type I canal configuration. No statistical correlation was found between number of roots, gender and tooth position. Conclusion: This cone-beam computed tomographic study confirmed previous anatomical and morphological investigations. Therefore, the possibility of additional root canals should be considered when treating premolars.

\section{KEYWORDS}

Cone-Beam Computed Tomography; Mandibular; Maxillary; Premolar; Root Canal; Morphology. tinham 3 raízes. No grupo de segundos pré-molares mandibulares $(\mathrm{n}=200), 90.1 \%$ tinham 1 raiz, 6.4\% tinham 2 raízes e $3.5 \%$ tinham 3 raízes, com a maioria exibindo configuração tipo I. Nenhuma correlação estatística foi encontrada entre número de raízes, gênero e posição do dente. Conclusão. O presente estudo usando tomografia computadorizada de feixe cônico confirmou investigações anatômicas e morfológicas anteriores. Portanto, a possibilidade de canais radiculares adicionais deve ser considerada quando do tratamento de pré-molares.

\section{PALAVRAS-CHAVE}

Tomografia computadorizada de feixe cônico; Mandibular; Maxilar; Pré-molar, Canal radicular; Morfologia.

\section{INTRODUCTION}

T $\mathrm{n}$ last century, the complexity of internal $\perp$ and external anatomical variations of roots and root canals has been documented. The first attempts were made by Hess and Zurcher [1], who visualised lateral canals and isthmi. Vertucci et al. [2] suggested a classification that is still used despite the recent implementation of further sub-classes. Numerous techniques have been developed and implemented to investigate the root canal anatomy, such as canal staining and tooth clearing techniques [3] as well as alternative and conventional imaging methods [4]. Recently, micro-computed tomography has been used for anatomy studies. This method allows the root canal system to be assessed non-invasively and three-dimensionally [5].

However, these studies are timeconsuming and their results based mainly on relatively small sample sizes. The better the diagnostic methods are, more sub-groups of root canal classifications are proposed [6]. Hence, recently, a new system for classifying roots and root canal systems was proposed based on Vertucci et al's classification to simplify research, clinical practice and training [7]. Because of the limitation of CT studies of extracted teeth, other three-dimensional data from medical computed tomographic imaging or cone-beam computed tomographic (CBCT) imaging may be helpful for the assessment of anatomical variations of teeth. Gender and race of the patients are usually listed in the medical record, including other pre-existing data.

Data from CBCT scans are well suited for assessing the root canal classifications in anatomical and morphological terms [8]. Because of the variability of the root canal morphology, especially in maxillary and mandibular first and second premolars, root canal treatment is challenging and its outcome may be poor [9]. Knowledge on the morphology of root and root canal is crucial for proper chemo-mechanical disinfection of the entire root canal system. Successful endodontic therapy depends to a large extent on thorough mechanical cleansing of each root canal [10]. These teeth often present an 8-shaped cross section with 1 or up to 3 roots that may occur fused or separate. Even with eccentric radiographs, important details may be superimposed by adjacent structures. Numerous studies investigated the prevalence of roots and root canals and a huge variability was documented depending upon selected method and ethnic group [11]. 
A recently published article showed that the majority of maxillary first premolars had 1 root $(46.0 \%)$ or 2 roots $(62.4 \%)$. Regardless of the number of roots, the vast majority (62.7\%) had 2 root canals, with type IV being the most common canal configuration $(52.8 \%)$ [12]. Vertucci's classification is relatively heterogeneously distributed. With regard to mandibular first and second premolars, their morphology also showed some variations, with the former commonly exhibiting 1 root (91.4\%), 2 roots $(8.6 \%)$ and 3 roots (5\%). The second mandibular premolar is usually a single-rooted tooth (98.6\%), with incidences of $2(1.3 \%)$ and 3 roots (3.5\%) [9]. In this study, we have evaluated the root canal morphology of maxillary and mandibular premolars in Chennai population by using CBCT data.

\section{MATERIALS AND METHODS}

Images of maxillary premolars were obtained between August 2016 and November 2017 from patients referred to the Department of Oral Medicine and Radiology Saveetha of the Dental College \& Hospital for CBCT scans as part of the treatment planning process. A total of 200 first and 200 second maxillary premolars as well as 200 first and 200 second mandibular premolars were obtained. All the eight premolars were analysed in single patients, who underwent cone-beam computed tomography scanning during pre-operative assessment (before implant surgery, orthodontic treatment, diagnosis of dento-alveolar trauma or difficult root canal treatment), after being selected according to the following criteria:

1. Availability of scans of maxillary first and/or second premolars

\section{Complete root formation}

3. Absence of root resorption, calcification or periapical lesions

4. Absence of root canal fillings, posts or crown restorations

5. Availability of a clear and complete view of the relevant teeth

6. Healthy teeth, both periodontically and endodontically.

\section{Image Acquisition}

CBCT images were obtained by using Dentsply Sirona 3D unit (Orthophos XG 3D). The operating parameters were 3-6 mA and 60-90 kV, with exposure time of 5.1 seconds. The smallest possible field of view was used $(8 \times 8 \mathrm{~cm})$ and isotropic voxel size was 0.16 $\mathrm{mm}$. The effective dose was between $14 \mu \mathrm{sv}$ $166 \mu$ sv. All CBCT scans were performed with the minimum exposure necessary for adequate image quality. The as low as reasonably achievable protocol was strictly followed. The patients were positioned parallel to the horizontal axis of the alveolar process, and the teeth under examination were placed in the centre of the volume. Number of root canal and canal configurations were investigated and classified according to the Vertucci's classification. (Figure 1)

During the experiment, the endodontist assessed the CBCT images independently and could scroll through axial, coronal and sagittal views of each tooth. In the event of disagreement, the case was discussed until a consensus was reached. 


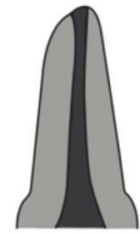

Type I

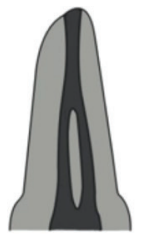

Type II

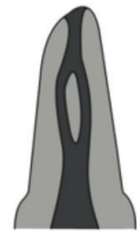

Type III

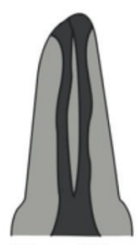

TypeIV

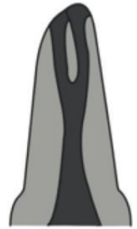

Type V

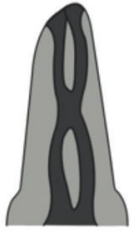

Type VI

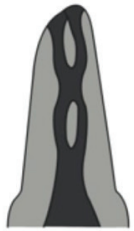

Type VII

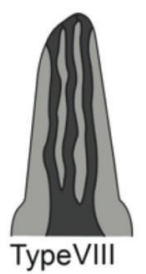

TypeVIII
Figure 1 - Diagrammatic representation of Vertucci's canal configuration.

The following information was recorded and analysed: sides

1. Tooth position relative to left and right

2. Number of roots and canal configuration, classified by using the Vertucci's criteria

\section{Number of apical foramina per root}

The number of roots detected in the axial plane of CBCT images was classified in accordance with Pecora et al13:

1. Single-rooted teeth: teeth with a clear single root and teeth with 2 independent canals that seemed to have 2 roots, which were actually fused;

2. Multi-rooted teeth: 2-rooted teeth possessing bifurcated roots, regardless of whether they were partial or complete, and 3 -rooted teeth, with 3 completely independent roots from the chamber floor, or bifurcations at any position along the buccal or palatal roots.

\section{Statistical Analysis}

Differences in root canal morphology and gender were determined by using the chisquare test and were considered significant if $\mathrm{P}$ value was $<.05$ (Table 2). Statistical procedure was performed on SPSS version 19 running under Microsoft Window (Microsoft Corp) for a personal computer.

\section{RESULTS}

Frequency and distribution of the number of roots and root canals are shown in Table 1 . From 100 patients, a total of 800 premolars were examined (200 maxillary first and 200 maxillary second premolars and 200 mandibular first and 200 mandibular second premolars).

\section{Maxillary First Premolars}

Most of the maxillary first premolars had 2 roots $(56.7 \%)$ (Table 1 ), which was approximately double of those with 1 root (36.3\%). The prevalence of 3 roots was rare (7\%) and the majority of maxillary first premolars showed Vertucci's type IV classification (30.4\%).

\section{Maxillary Second Premolars}

Most teeth showed 1 root (60\%), but more than a half presented 2 root canals $(29.8 \%)$. The majority of maxillary second premolars showed Vertucci's type IV (32.2\%) and V (28.3\%) classifications.

\section{Mandibular First Premolar}

Among these teeth, the great majority had 1 root canal (80.5\%), but more than one fifth of the teeth showed $2(9.8 \%)$ and $3(5 \%)$ roots. Root canal morphology showed huge variations as type classification ranged from I to VIII, with Vertucci's type I (40.1\%) and V (28.1\%) occurring in the majority of the cases.

\section{Mandibular Second Premolars}

Nearly all teeth had only 1 root (90.1\%), whereas the remaining ones had $2(6.4 \%)$ and 3 roots $(3.5 \%)$. Vertucci's type I $(56.1 \%)$ occurred in the majority of the cases.

No statistical difference was found between root number and gender $(\mathrm{P}>.05)$ (Table 2). As for the type of root canal, no significant differences were found either $(\mathrm{P}>.05)$. 
Table 1 - Prevalence of root canal type and root (\% of teeth) According to Gender.

\begin{tabular}{|c|c|c|c|c|c|c|c|c|c|c|c|c|}
\hline \multirow{2}{*}{\multicolumn{2}{|c|}{ Tooth }} & \multicolumn{3}{|c|}{ No. of Roots (\%) } & \multicolumn{8}{|c|}{ Vertucci Classification (\%) } \\
\hline & & 1 & 2 & 3 & I & \| & III & IV & V & VI & VII & VIII \\
\hline 14 & Male & 23.0 & 32.0 & 2.0 & 6.0 & 6.0 & 4.0 & 26.0 & 10.0 & 1.0 & 1.0 & 3.0 \\
\hline & Female & 20.0 & 19.0 & 4.0 & 4.0 & 3.0 & 2.0 & 16.0 & 13.0 & 1.0 & 1.0 & 3.0 \\
\hline 14 & Total & 43.0 & 51.0 & 6.0 & 10.0 & 9.0 & 6.0 & 42.0 & 23.0 & 2.0 & 2.0 & 6.0 \\
\hline 24 & Male & 16.0 & 39.0 & 2.0 & 9.0 & 8.0 & 8.0 & 13.0 & 8.0 & 5.0 & 4.0 & 2.0 \\
\hline & Female & 13.0 & 25.0 & 5.0 & 6.0 & 5.0 & 10.0 & 7.0 & 6.0 & 1.0 & 5.0 & 3.0 \\
\hline & Total & 29.0 & 64.0 & 7.0 & 15.0 & 13.0 & 18.0 & 20.0 & 14.0 & 6.0 & 9.0 & 5.0 \\
\hline \multicolumn{2}{|c|}{ Total Male } & 34.2 & 62.3 & 3.5 & 13.2 & 12.3 & 10.5 & 34.2 & 15.8 & 5.3 & 4.4 & 4.4 \\
\hline \multicolumn{2}{|c|}{ Total Female } & 38.4 & 51.2 & 10.5 & 11.6 & 9.3 & 14.0 & 26.7 & 22.1 & 2.3 & 7.0 & 7.0 \\
\hline \multicolumn{2}{|c|}{ Total } & 36.3 & 56.7 & 7.0 & 12.5 & 10.8 & 12.2 & 30.4 & 18.9 & 3.8 & 5.7 & 5.7 \\
\hline 15 & Male & 33.0 & 20.0 & 4.0 & 4.0 & 2.0 & 1.0 & 20.0 & 14.0 & 5.0 & 3.0 & 8.0 \\
\hline & Female & 31.0 & 10.0 & 2.0 & 1.0 & 2.0 & 5.0 & 10.0 & 18.0 & 2.0 & 3.0 & 2.0 \\
\hline 15 & Total & 64.0 & 30.0 & 6.0 & 5.0 & 4.0 & 6.0 & 30.0 & 32.0 & 7.0 & 6.0 & 10.0 \\
\hline 25 & Male & 27.0 & 20.0 & 10.0 & 3.0 & 1.0 & 4.0 & 23.0 & 16.0 & 4.0 & 3.0 & 3.0 \\
\hline & Female & 27.0 & 11.0 & 5.0 & 1.0 & 5.0 & 6.0 & 13.0 & 8.0 & 2.0 & 3.0 & 5.0 \\
\hline 25 & Total & 54.0 & 31.0 & 15.0 & 4.0 & 6.0 & 10.0 & 36.0 & 24.0 & 6.0 & 6.0 & 8.0 \\
\hline \multicolumn{2}{|c|}{ Total Male } & 52.6 & 35.1 & 12.3 & 6.1 & 2.6 & 4.4 & 37.7 & 26.3 & 7.9 & 5.3 & 9.6 \\
\hline \multicolumn{2}{|c|}{ Total Female } & 67.4 & 24.4 & 8.1 & 2.3 & 8.1 & 12.8 & 26.7 & 30.2 & 4.7 & 7.0 & 8.1 \\
\hline \multicolumn{2}{|c|}{ Total } & 60.0 & 29.8 & 10.2 & 4.2 & 5.4 & 8.6 & 32.2 & 28.3 & 6.3 & 6.1 & 8.9 \\
\hline 34 & Male & 47.0 & 7.0 & 3.0 & 25.0 & 2.0 & 2.0 & 5.0 & 16.0 & 3.0 & 1.0 & 3.0 \\
\hline & Female & 34.0 & 4.0 & 5.0 & 18.0 & 4.0 & 1.0 & 1.0 & 11.0 & 5.0 & 2.0 & 1.0 \\
\hline 34 & Total & 81.0 & 11.0 & 8.0 & 43.0 & 6.0 & 3.0 & 6.0 & 27.0 & 8.0 & 3.0 & 4.0 \\
\hline 44 & Male & 45.0 & 6.0 & 6.0 & 32.0 & 1.0 & 1.0 & 1.0 & 19.0 & 1.0 & 1.0 & 1.0 \\
\hline 44 & Female & 35.0 & 3.0 & 5.0 & 8.0 & 5.0 & 4.0 & 6.0 & 11.0 & 1.0 & 1.0 & 7.0 \\
\hline 44 & Total & 80.0 & 9.0 & 11.0 & 40.0 & 6.0 & 5.0 & 7.0 & 30.0 & 2.0 & 2.0 & 8.0 \\
\hline \multicolumn{2}{|c|}{ Total Male } & 80.7 & 11.4 & 4.9 & 50.0 & 2.6 & 2.6 & 5.3 & 30.7 & 3.5 & 1.8 & 3.5 \\
\hline \multicolumn{2}{|c|}{ Total Female } & 80.2 & 8.1 & 9.6 & 30.2 & 10.5 & 5.8 & 8.1 & 25.6 & 7.0 & 3.5 & 9.3 \\
\hline \multicolumn{2}{|c|}{ Total } & 80.5 & 9.8 & 5.0 & 40.1 & 6.5 & 4.2 & 6.7 & 28.1 & 5.2 & 2.6 & 6.4 \\
\hline 35 & Male & 51.0 & 4.0 & 2.0 & 32.0 & 5.0 & 4.0 & 4.0 & 6.0 & 2.0 & 1.0 & 3.0 \\
\hline & Female & 39.0 & 3.0 & 1.0 & 28.0 & 1.0 & 5.0 & 2.0 & 3.0 & 1.0 & 2.0 & 1.0 \\
\hline 35 & Total & 90.0 & 7.0 & 3.0 & 60.0 & 6.0 & 9.0 & 6.0 & 9.0 & 3.0 & 3.0 & 4.0 \\
\hline 45 & Male & 51.0 & 4.0 & 2.0 & 31.0 & 5.0 & 3.0 & 1.0 & 12.0 & 2.0 & 1.0 & 2.0 \\
\hline 45 & Female & 39.0 & 20 & 2.0 & 21.0 & 5.0 & 2.0 & 3.0 & 5.0 & 1.0 & 3.0 & 3.0 \\
\hline & Total & 90.0 & 6.0 & 4.0 & 52.0 & 10.0 & 5.0 & 4.0 & 17.0 & 3.0 & 4.0 & 5.0 \\
\hline \multicolumn{2}{|c|}{ Total Male } & 89.5 & 7.0 & 3.5 & 55.3 & 8.8 & 6.1 & 4.4 & 15.8 & 3.5 & 1.8 & 4.4 \\
\hline \multicolumn{2}{|c|}{ Total Female } & 90.7 & 5.8 & 3.5 & 57.0 & 7.0 & 8.1 & 5.8 & 9.3 & 2.3 & 5.8 & 4.7 \\
\hline \multicolumn{2}{|c|}{ Total } & 90.1 & 6.4 & 3.5 & 56.1 & 7.9 & 7.1 & 5.1 & 12.5 & 2.9 & 3.8 & 4.5 \\
\hline
\end{tabular}


Table 1 - Representing $x^{2}$ test and $p$-value.

\begin{tabular}{|c|c|c|c|c|c|c|c|c|c|c|c|c|}
\hline \multirow{2}{*}{\multicolumn{2}{|c|}{ Tooth }} & \multicolumn{3}{|c|}{ No. of Roots (\%) } & \multicolumn{8}{|c|}{ Vertucci Classification (\%) } \\
\hline & & 1 & 2 & 3 & I & \|I & III & IV & V & VI & VII & VIII \\
\hline 14 & Male & 23.0 & 32.0 & 2.0 & 6.0 & 6.0 & 4.0 & 26.0 & 10.0 & 1.0 & 1.0 & 3.0 \\
\hline \multirow[t]{3}{*}{14} & Female & 20.0 & 19.0 & 4.0 & 4.0 & 3.0 & 2.0 & 16.0 & 13.0 & 1.0 & 1.0 & 3.0 \\
\hline & $\mathrm{X}^{2}$-value & & 2.274 & & \multicolumn{8}{|c|}{2.936} \\
\hline & $\mathrm{p}$-value & & 0.321 & & \multicolumn{8}{|c|}{0.891} \\
\hline 24 & Male & 16.0 & 39.0 & 2.0 & 9.0 & 8.0 & 8.0 & 13.0 & 8.0 & 5.0 & 4.0 & 2.0 \\
\hline \multirow[t]{3}{*}{24} & Female & 13.0 & 25.0 & 5.0 & 6.0 & 5.0 & 10.0 & 7.0 & 6.0 & 1.0 & 5.0 & 3.0 \\
\hline & $X^{2}$-value & & 2.753 & & \multicolumn{8}{|c|}{4.710} \\
\hline & $\mathrm{p}$-value & & 0.253 & & \multicolumn{8}{|c|}{0.695} \\
\hline 15 & Male & 33.0 & 20.0 & 4.0 & 4.0 & 2.0 & 1.0 & 20.0 & 14.0 & 5.0 & 3.0 & 8.0 \\
\hline \multirow[t]{3}{*}{15} & Female & 31.0 & 10.0 & 2.0 & 1.0 & 2.0 & 5.0 & 10.0 & 18.0 & 2.0 & 3.0 & 2.0 \\
\hline & $\mathrm{X}^{2}$-value & & 2.145 & & \multicolumn{8}{|c|}{2.450} \\
\hline & $\mathrm{p}$-value & & 0.342 & & \multicolumn{8}{|c|}{0.120} \\
\hline 25 & Male & 27.0 & 20.0 & 10.0 & 3.0 & 1.0 & 4.0 & 23.0 & 16.0 & 4.0 & 3.0 & 3.0 \\
\hline \multirow[t]{3}{*}{25} & Female & 27.0 & 11.0 & 5.0 & 1.0 & 5.0 & 6.0 & 13.0 & 8.0 & 2.0 & 3.0 & 5.0 \\
\hline & $X^{2}$-value & & 2.366 & & \multicolumn{8}{|c|}{2.450} \\
\hline & $\mathrm{p}$-value & & 0.306 & & \multicolumn{8}{|c|}{0.120} \\
\hline 34 & Male & 47.0 & 7.0 & 3.0 & 25.0 & 2.0 & 2.0 & 5.0 & 16.0 & 3.0 & 1.0 & 3.0 \\
\hline \multirow[t]{3}{*}{34} & Female & 34.0 & 4.0 & 5.0 & 18.0 & 4.0 & 1.0 & 1.0 & 11.0 & 5.0 & 2.0 & 1.0 \\
\hline & $\mathrm{X}^{2}$-value & & 1.473 & & \multicolumn{8}{|c|}{5.718} \\
\hline & $\mathrm{p}$-value & & 0.479 & & \multicolumn{8}{|c|}{0.573} \\
\hline 44 & Male & 45.0 & 4.0 & 6.0 & 32.0 & 1.0 & 1.0 & 1.0 & 19.0 & 1.0 & 1.0 & 1.0 \\
\hline \multirow[t]{3}{*}{44} & Female & 35.0 & 3.0 & 5.0 & 8.0 & 5.0 & 4.0 & 6.0 & 11.0 & 1.0 & 1.0 & 7.0 \\
\hline & $X^{2}$-value & & 0.389 & & \multicolumn{8}{|c|}{2.653} \\
\hline & $\mathrm{p}$-value & & 0.823 & & \multicolumn{8}{|c|}{0.678} \\
\hline 35 & Male & 51.0 & 4.0 & 2.0 & 32.0 & 5.0 & 4.0 & 4.0 & 6.0 & 2.0 & 1.0 & 3.0 \\
\hline \multirow[t]{3}{*}{35} & Female & 39.0 & 3.0 & 1.0 & 28.0 & 1.0 & 5.0 & 2.0 & 3.0 & 1.0 & 2.0 & 1.0 \\
\hline & $\mathrm{X}^{2}$-value & & 0.119 & & \multicolumn{8}{|c|}{4.506} \\
\hline & $\mathrm{p}$-value & & 0.942 & & \multicolumn{8}{|c|}{0.720} \\
\hline 45 & Male & 51.0 & 4.0 & 2.0 & 31.0 & 5.0 & 3.0 & 1.0 & 12.0 & 2.0 & 1.0 & 2.0 \\
\hline \multirow[t]{3}{*}{45} & Female & 39.0 & 2.0 & 1.0 & 21.0 & 5.0 & 2.0 & 3.0 & 5.0 & 1.0 & 3.0 & 3.0 \\
\hline & $\mathrm{X}^{2}$-value & & 0.313 & & \multicolumn{8}{|c|}{5.690} \\
\hline & $\mathrm{p}$-value & & 0.855 & & & & & & & & & \\
\hline
\end{tabular}




\section{DISCUSSION}

This study has investigated the root and root canal morphologies of maxillary and mandibular premolars in a Chennai population by using CBCT imaging. To the best of the authors' knowledge, comparable data on Chennai patients have not been published yet. A thorough knowledge of the root anatomy and canal morphology is crucial for a successful root canal therapy [14]. The present study included CBCT scans of 100 patients, resulting in a huge number of teeth and allowing comparison of the localisation of the teeth and gender distribution of the different morphologies. The results concerning the root and root canal morphologies in a Chennai population were comparable to other studies in Chinese populations [15].

In maxillary first premolars, the frequency of 1-rooted teeth (36.3\%) was lower than that reported for the Spanish population [12], whereas the frequency of 2-rooted (56.7\%) and 3 -rooted $(7 \%)$ teeth was higher than that for the German population [9]. In mandibular second premolars, the frequency of 2-rooted (29.8\%) and 3-rooted (10.2\%) teeth was higher than that for German, European and Spanish populations [12]. In maxillary second premolars, the frequency of 1-rooted teeth (60\%) was lower than that reported elsewhere [16], whereas the frequency of 2-rooted (29.8\%) and 3-rooted $(10.2 \%)$ teeth was higher than that for the German population [9]. In mandibular first premolars, the frequency of 1-rooted teeth $(80.5 \%)$ was lower than that reported elsewhere [12], whereas the frequency of 2-rooted (9.8\%) 3 -rooted (5\%) teeth was higher than that for the Turkish population [16].

Several studies have reported on the quality of CBCT imaging and its clinical applications in the study of root canal morphology before endodontic treatment [3][9][15]. When abnormal findings are not evident on traditional periapical films and variations are detected only with magnification in the clinical setting, it may be impossible to evaluate the root canal system effectively [17]. In these situations, it is sensible to use CBCT for further diagnosis.
Images free of superimposition of structures allow a three-dimensional anatomical view with high geometrical accuracy, which seems to be suited for detailed assessment of root and root canal morphologies [18]. However, in vivo investigations using CBCT have some limitations because additional artefacts may reduce the image quality (e.g., noise, scattering, extinction artefacts, beam-hardening artefacts, exponential edge gradient effects, aliasing artefacts, ring artefacts, and motion artefacts) [19]. The aim is to reduce the 37 root canal configuration types in a single root into more clinically relevant types [12]. In the present study, the anatomy of root canals was categorised into 8 types according to the Vertucci's classification. No further sub-groups were considered for comparison of our results with those of preexisting investigations. It should be mentioned that the implementation of countless new subgroups of Vertucci's classification lacks clinical relevance because, in the majority of the cases, the mechanical preparation during root canal treatment is still limited to the main root canals. A previous investigation on root canal anatomy of maxillary premolars by using CBCT scanning has yielded varied results [20]. This may be explained in part by the differences in CBCT resolution, radiographic interpretation and sample size.

\section{CONCLUSION}

Despite the limitation of the present study, we have shown that the Chennai population has most maxillary first premolars with 2 roots within the Vertucci's type IV classification and maxillary second premolars with 1 root, whereas mandibular first and second premolars tended to be single-rooted within the Vertucci's type I classification. Overall, no statistical differences were found between number of roots, type of canal and gender. In vivo CBCT analysis is a non-invasive and clinically effective tool for examining root and root canals morphologically that may ultimately improve the outcome of endodontic treatment. 


\section{REFERENCES}

1. Jain A, Bahuguna R. Root canal morphology of mandibular first premolar in a gujarati population - an in vitro study. Dent Res J (Isfahan). 2011 Summer;8(3):118-22

2. Ahmed HMA, Versiani MA, De-Deus G, Dummer PMH. A new system for classifying root and root canal morphology. Int Endod J. 2017 Aug;50(8):761770. doi: 10.1111/iej.12685. Epub 2016 0ct 17.

3. Neelakantan P, Subbarao C, Ahuja R, Subbarao CV. Root and canal morphology of Indian maxillary premolars by a modified root canal staining technique. Odontology. 2011 Jan;99(1):18-21. do: 10.1007/s10266-010-0137-0. Epub 2011Jan 27.

4. Patel S, Dawood A, Whaites E, Pitt Ford T. New dimensions in endodontic imaging: part 1. Conventional and alternative radiographic systems. Int Endod J. 2009 Jun;42(6):447-62. doi:10.1111/j.1365-2591.2008.01530.x. Epub 2009 Mar 2.

5. Tomaszewska IM, Leszczyński B, Wróbel A, Gładysz T, Duncan HF. microcomputed tomographic (micro-CT) analysis of the root canal morphology of maxillary third molar teeth. Ann Anat. 2018 Jan;215:83-92. doi: 10.1016/j. aanat.2017.09.003. Epub 2017 Sep 24.

6. Versiani MA, Ordinola-Zapata R, Keleş A, Alcin H, Bramante CM, Pécora JD, et al. Middle mesial canals in mandibular first molars: A micro-CT study in different populations. Arch Oral Biol. 2016 Jan;61:130-7. doi:10.1016/j. archoralbio.2015.10.020. Epub 2015 Nov 4.

7. Ahmed HMA, Dummer PMH. Advantages and Applications of a New System for Classifying Roots and Canal Systems in Research and Clinical Practice. Eur Endod J. 2018;3(1):9-17.

8. VertucciFJ. Root canal anatomy of the human permanent teeth. Oral Surg Oral Med Oral Pathol. 1984 Nov;58(5):589-99.

9. Bürklein S, Heck R, Schäfer E. Evaluation of the Root Canal Anatomy of Maxillary and Mandibular Premolars in a Selected German Population Using Cone-beam Computed Tomographic Data. J Endod. 2017 Sep;43(9):14481452. doi:10.1016/j.joen.2017.03.044. Epub 2017 Jul 22.

10. Vertucci F, Seelig A, Gillis R. Root canal morphology of the human maxillary second premolar. Oral Surg Oral Med Oral Pathol. 1974 Sep;38(3):456-64.
11. Al-Ghananeem MM, Haddadin K, Al-Khreisat AS, Al-Weshah M, Al-Habahbeh $N$. The number of roots and canals in the maxillary second premolars in a group of jordanian population. International journal of dentistry. 2014;2014.

12. Abella F, Teixidó LM, Patel S, Sosa F, Duran-Sindreu F, Roig M. Cone-beam Computed Tomography Analysis of the Root Canal Morphology of Maxillary First and Second Premolars in a Spanish Population. J Endod. 2015 Aug;41(8):1241-7. doi: 10.1016/j.joen.2015.03.026. Epub 2015 May 5.

13. Pécora JD, Saquy PC, Sousa Neto MD, Woelfel JB. Root form and canal anatomy of maxillary first premolars. Braz Dent J. 1992;2(2):87-94.

14. Bulut DG, Kose E, Ozcan G, Sekerci AE, Canger EM, Sisman Y.Evaluation of root morphology and root canal configuration of premolars in the Turkish individuals using cone beam computed tomography. Eur J Dent. 2015 OctDec;9(4):551-7. doi:10.4103/1305-7456.172624.

15. Wang Y, Zheng $Q H$, Zhou XD, Tang L, Wang Q, Zheng GN, et al. Evaluation of the root and canal morphology of mandibular first permanent molars in a western Chinese population by cone-beam computed tomography. J Endod. 2010 Nov;36(11):1786-9. doi: 10.1016/j.joen.2010.08.016. Epub 2010 Sep 17.

16. Özcan E, Çolak H, Hamidi MM. Root and canal morphology of maxillary first premolars in a Turkish population. J Dent Sci. 2012;7(4):390-4.

17. Abella F, Patel S, Durán-Sindreu F, Mercadé M, Roig M. Mandibular first molars with disto-lingual roots: review and clinical management. Int Endod J. 2012 Nov;45(11):963-78. doi: 10.1111/.1365-2591.2012.02075.x. Epub 2012 Jun 11.

18. de Oliveira MVL, Santos AC, Paulo G, Campos PSF, Santos J. Application of a newly developed software program for image quality assessment in conebeam computed tomography. Imaging Sci Dent. 2017 Jun;47(2):75-86. doi: 10.5624/isd.2017.47.2.75. Epub2017 Jun22.

19. Zhao W, Vernekohl D, Zhu J, Wang L, Xing L. A model-based scatter artifacts correction for cone beam CT. Med Phys. 2016 Apr;43(4):1736. doi: 10.1118/1.4943796.

20. Tian YY, Guo B, Zhang R, YuX, Wang H, Hu T, et al. Root and canal morphology of maxillary first premolars in a Chinese subpopulation evaluated using cone-beam computed tomography. Int Endod J. 2012 Nov;45(11):996-1003. doi:10.1111/j.1365-2591.2012.02059.x. Epub 2012 May 2.

???

(Corresponding address)

???? 